\title{
Geologic Investigation of a Potential Site for a Next-Generation Reactor Neutrino Oscillation Experiment - Diablo Canyon, San Luis Obispo County, CA
}

\author{
Celia Tiemi Onishi, Patrick Dobson, and Seiji Nakagawa \\ Earth Sciences Division, Lawrence Berkeley National Laboratory, Berkeley, \\ CA 94720, USA \\ Steven Glaser and Dom Galic \\ Department of Civil and Environmental Engineering, University of California, Berkeley, \\ CA 94720 USA
}

June 2004 


\section{CONTENTS}

Page

Abstract 3

1. Introduction 4

2. Background of Neutrino Project 5

3. Data Acquisition 6

3.1. Geologic Setting 6

3.2. Geologic Cross Section Profile 8

3.3. Field Site - Diablo Canyon, San Luis

$\begin{array}{ll}\text { Obispo County, CA } & 10\end{array}$

3.3.1. Rock Units 10

3.3.2. Structural Features 13

3.4. Rock Property Measurements 14

3.4.1. X-Ray Diffraction Analysis 15

3.4.2. Gamma-Ray Spectrometric Analysis 15

3.4.3. Grain Density and Porosity 16

3.4.4. Rock Elastic Moduli (dynamic) and $\begin{array}{ll}\text { Strength measurements } & 18\end{array}$

4. Geologic Hazards 24

4.1. Landslide 24

4.2. Seismic Hazards 24

4.3. Water Table 25

4.4. Presence of Hydrocarbons 26

4.5. Subsurface Temperature 26

4.6. Swelling Clays 26

5. Summary 26

6. References 27

$\begin{array}{ll}\text { Appendix } 1 & 29\end{array}$ 


\begin{abstract}
This report provides information on the geology and selected physical and mechanical properties of surface rocks collected at Diablo Canyon, San Luis Obispo County, California as part of the design and engineering studies towards a future reactor neutrino oscillation experiment. The main objective of this neutrino project is to study the process of neutrino flavor transformation-or neutrino oscillation-by measuring neutrinos produced in the fission reactions of a nuclear power plant. Diablo Canyon was selected as a candidate site because it allows the detectors to be situated underground in a tunnel close to the source of neutrinos (i.e., at a distance of several hundred meters from the nuclear power plant) while having suitable topography for shielding against cosmic rays. The detectors have to be located underground to minimize the cosmic ray-related background noise that can mimic the signal of reactor neutrino interactions in the detector.
\end{abstract}

Three Pliocene-Miocene marine sedimentary units dominate the geology of Diablo Canyon: the Pismo Formation, the Monterey Formation, and the Obispo Formation. The area is tectonically active, located east of the active Hosgri Fault and in the southern limb of the northwest trending Pismo Syncline. Most of the potential tunnel for the neutrino detector lies within the Obispo Formation. Review of previous geologic studies, observations from a field visit, and selected physical and mechanical properties of rock samples collected from the site provided baseline geological information used in developing a preliminary estimate for tunneling construction cost. Gamma-ray spectrometric results indicate low levels of radioactivity for uranium, thorium, and potassium. Grain density, bulk density, and porosity values for these rock samples range from 2.37 to $2.86 \mathrm{~g} / \mathrm{cc}, 1.41$ to $2.57 \mathrm{~g} / \mathrm{cc}$, and 1.94 to $68.5 \%$ respectively. Point load, unconfined compressive strength, and ultrasonic velocity tests were conducted to determine rock mechanical and acoustic properties. The rock strength values range from 23 to $219 \mathrm{MPa}$ and the Poisson's ratio from 0.1 to 0.38 . Potential geologic hazards in the Diablo Canyon area were identified and described to provide an overall picture of processes that may affect tunnel construction activities. 


\section{Introduction}

The Diablo Canyon Nuclear Power Plant site in San Luis Obispo County, California, has been identified by the LBNL Neutrino Project group as one of the best candidate sites for conducting a neutrino experiment to measure the last unknown neutrino mixing angle $\theta_{13}$. In such an experiment, a tunnel would be excavated horizontally into the hills close to the power plant to accommodate two or more mobile detectors to measure the reactor neutrino flux as a function of distance from the reactor. This study summarizes the influence of local geologic features and rock properties on engineering issues associated with tunnel construction for the neutrino experiment.

The geology of Diablo Canyon is dominated by Pliocene-Miocene sedimentary rocks, with abundant dolomitic sandstones of the Pliocene Obispo Formation (William Lettis and Associates, 2001a) and siliceous deposits of the Miocene Monterey Formation (Isaacs, 1981; Chaika and Dvorkin, 2000). The steep topography close to the power plant offers natural shielding for an undergound neutrino detector. Detailed geologic studies have been conducted by PG\&E just south of the proposed tunnel entrance to evaluate rock properties, slope stability, and ground motion (William Lettis and Associates, 2001a).

A geologic cross section along the potential tunnel was constructed based on geologic maps (Hall et al., 1979), to show the local geology and to identify possible problems related to tunnel construction for the Neutrino Project. In addition, selected outcrop samples were characterized for their chemical, physical, mechanical and acoustic properties, and a brief geologic reconnaissance of the site was conducted. This report also discusses other geologic features and processes (e.g., ground motion, landslides, water table location, subsurface temperatures, swelling clays) that occur at the Diablo Canyon site. 


\section{Background of Neutrino Project}

A neutrino is a subatomic, pointlike particle. It belongs to the family of leptons, has no electrical charge, and very small mass. Neutrinos are one of the most abundant particles in the universe. These tiny particles travel through the universe at close to the speed of light. They were created by the Big Bang and continue to be created in nuclear reactions and particle interactions. From the Big Bang to the present, neutrinos have played a crucial role in the evolution of the universe. Neutrinos are also created by the interaction of cosmic rays with the atmosphere of the Earth and emitted during radioactive decay of elements inside the Earth.

In addition, man-made neutrinos are produced in nuclear reactions inside nuclear power plants and during particle interactions at accelerators like the ones at Fermilab and the European Center for Nuclear Research (CERN). Depending on the source and the environment in which neutrinos are produced, different types of neutrinos are created.

$\begin{array}{lrrrr}\text { Recent experiments } & \text { such } & \text { as } & \text { Super-Kamiokande } & (\underline{\text { http://www-sk.icrr.u- }} \\ \text { tokyo.ac.jp/doc/sk/), } & \text { the } & \text { Sudbury } & \text { Neutrino } & \text { Observatory }\end{array}$
(http://www.sno.phy.queensu.ca/), and KamLAND (http://kamland.lbl.gov) have shown that neutrinos oscillate between three "flavors"-electron, muon, and tau. These experiments have been able to measure two of the three-neutrino mixing angles that describe the flavor transformation of neutrinos. One of the neutrino mixing angles, $\theta_{13}$, is yet unknown and may hold the clue to understanding the observed matter-antimatter asymmetry in the universe. Nuclear reactors provide an intense source of anti-neutrinos, and the required sensitivity to measure theta 13 can be achieved (Anderson et al., 2004). In nuclear reactors, anti-electron neutrinos are emitted in fission reactions with a mean energy of $4 \mathrm{MeV}$. A neutrino detector uses the inverse beta-decay reaction (anti-neutrino + proton --> neutron + positron) to detect anti-neutrinos. It detects the photons emitted from a scintillator when the neutron is absorbed by matter and when the anti-electron coming from the neutrino interaction annihilates with an electron of matter. Neutrino 
studies offer great prospect for understanding the fundamental properties of the universe and yield answers to some of the most profound questions in physical science.

The Diablo Canyon Neutrino Project proposes to construct a tunnel to house movable detectors for a neutrino experiment near the Diablo Canyon Nuclear Power Plant, CA, operated by PG\&E. The proposed site is ideal for the experiment because of the excellent source of neutrinos from the reactors, and the nearby presence of hills that would serve to shield the detectors from cosmic-ray and cosmic-ray-related background neutrinos.

\section{Data Acquisition}

\subsection{Geologic setting}

The proposed location for constructing a tunnel for the neutrino detector facility is located $20 \mathrm{~km}$ southwest of San Luis Obispo, California at Diablo Canyon. The geology of Diablo Canyon is dominated by Pliocene-Miocene marine sedimentary units (the Pismo Monterey and Obispo Formations) and by a Miocene diabasic/basaltic unit. The rocks present in the area around the potential tunnel site are predominantly comprised of the older sedimentary and volcaniclastic rocks of the Obispo Formation (consisting of tuffaceous and dolomitic sandstones, siltstones and claystones, siliceous porcelanite, and chert) and an unnamed Tertiary volcanic unit (comprised by basaltic flows and diabasic dikes and sills). Other units of interest include Quaternary alluvial deposits along the canyon floors and Quaternary landslide deposits found on some of the steep hillsides. A geologic map of the area from Hall et al. (1979) is presented in Figure 1. 


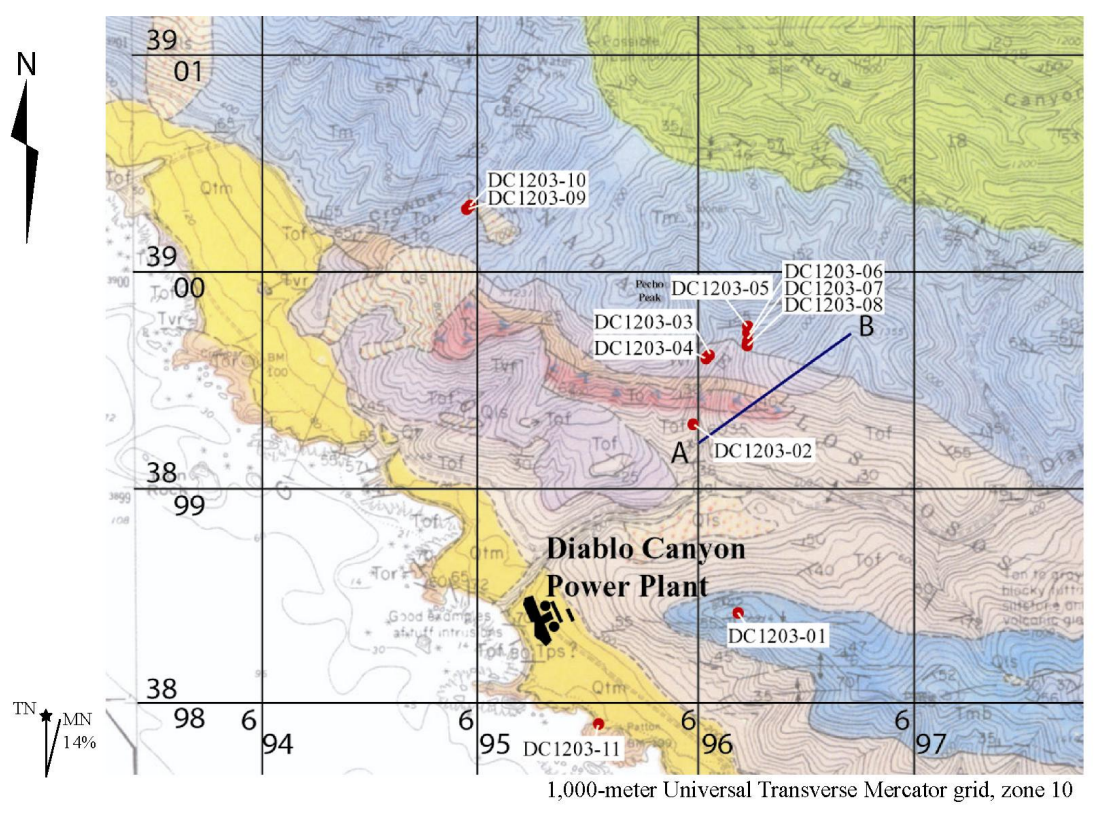

CORRELATION OF MAP UNITS

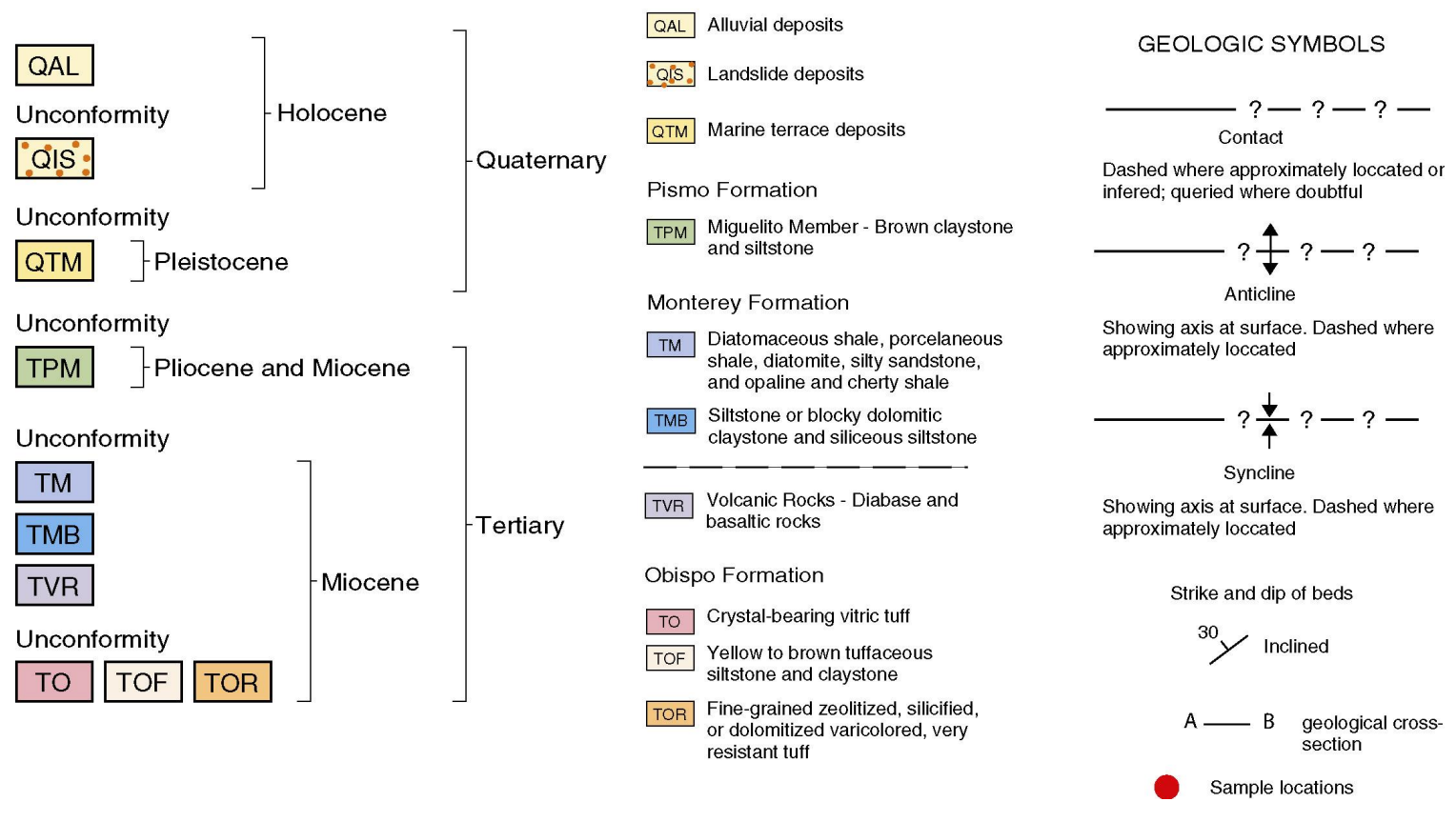

Figure 1. Geologic map of the Diablo Canyon area. Map from Hall et al. (1979). Cross section for proposed tunnel site is presented in Figure 2. For details about sample location see Table 1. 


\subsection{Geologic cross section profile}

The azimuth of the proposed tunnel trajectory at Diablo Canyon is N50E and extends approximately $850 \mathrm{~m}$ (Figure 2). The surface elevation at the portal (Figure 3), located along Dry Canyon Road, is approximately $97 \mathrm{~m}(\sim 320 \mathrm{ft})$ above sea level. A geologic cross section for this trajectory was constructed using surface contacts, bedding orientations, and structural data obtained from Hall et al. (1979). Detailed mapping conducted by William Lettis and Associates (2001a) for the adjacent proposed Independent Spent Fuel Storage Installation (ISFSI) area resulted in some changes from the Hall et al. (1979) map in the different Obispo lithologies, and thus it is expected that detailed mapping in the area of the proposed tunnel would also result in some changes to the lithologic contacts presented here. The tunnel location was projected along this cross section assuming a grade of $1 \%$ from the western portal. Exposures of tuffaceous and dolomitic sandstone and siltstone of the Obispo Formation are present in the proposed portal area. Other rock units overlying the tunnel include tuffaceous siltstones, sandstones, and chert of the Obispo Formation and basaltic/diabasic rocks (Tvr), and porcelanite, phosphatic and organic siliceous shales, and chert of the Monterey Formation (Tm). 


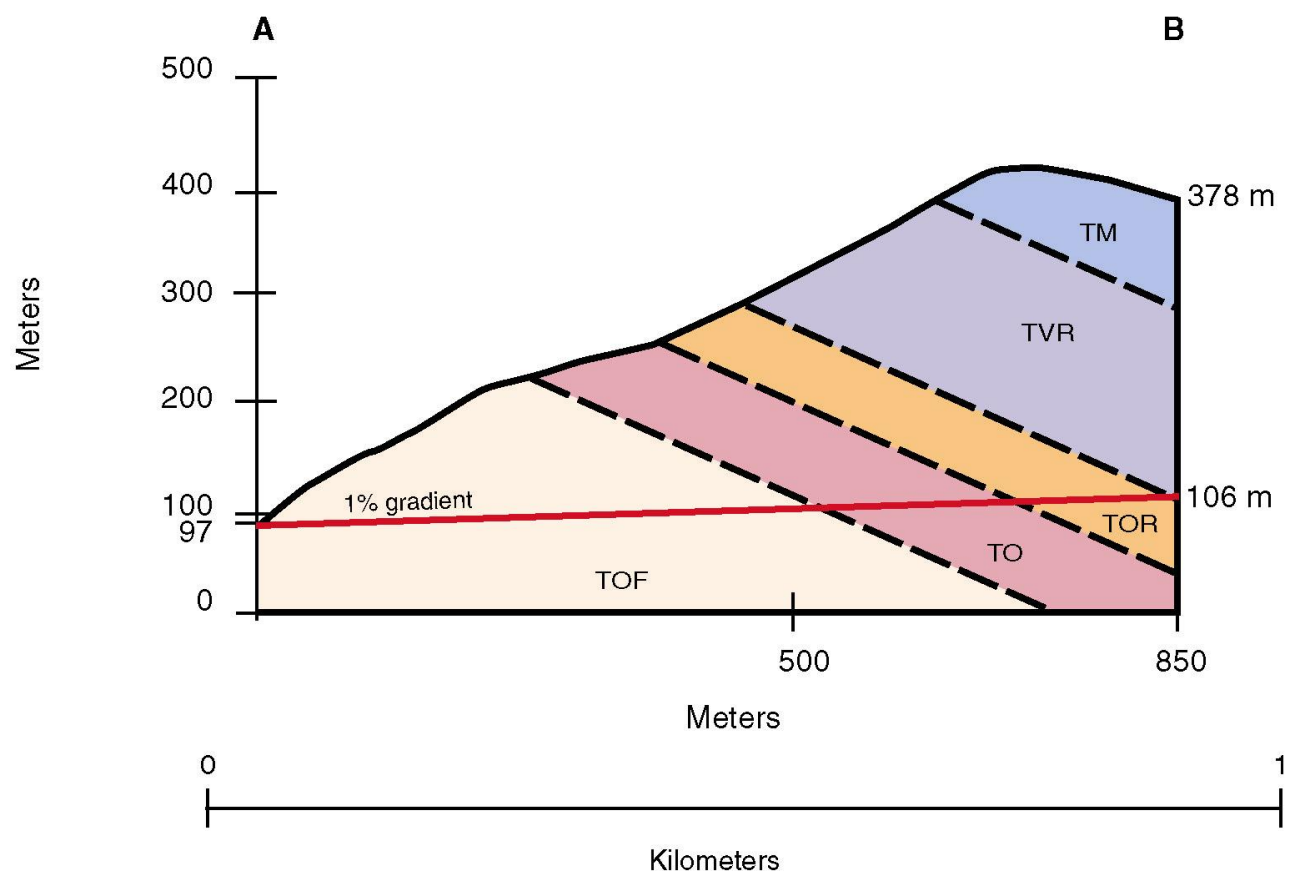

Figure 2. Geologic cross-section of proposed tunnel location. Geologic units are as indicated in Figure 1. Orientation of cross section is N50E.

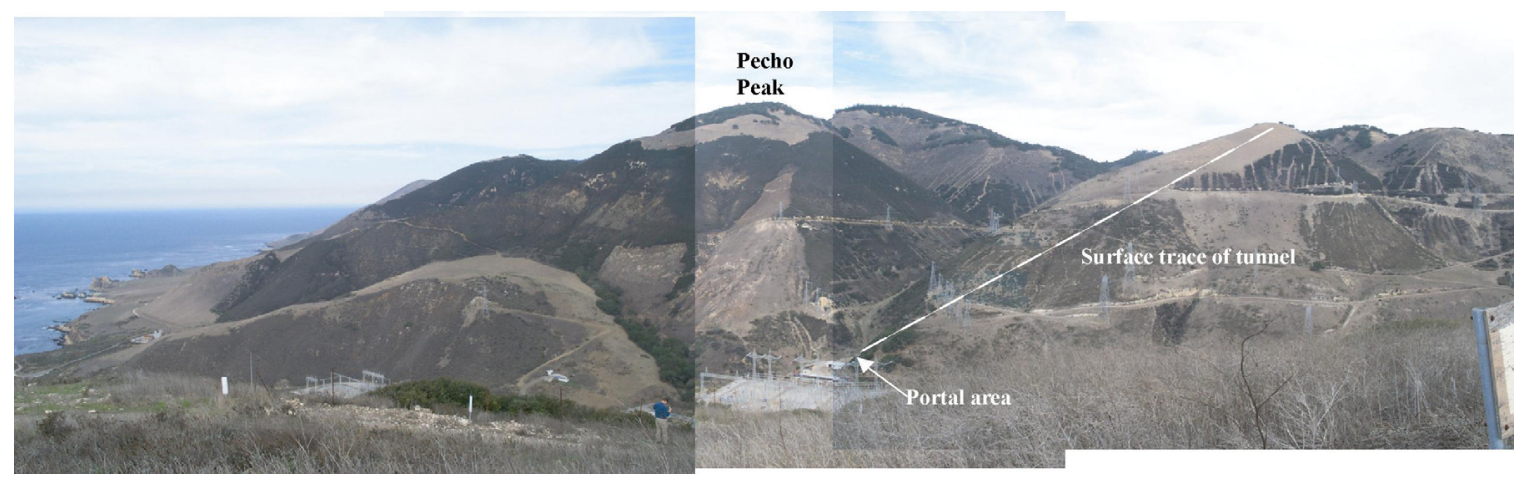

Figure 3. Panoramic overview of Diablo Canyon from south

The maximum vertical overburden for each unit along the tunnel profile is presented below. The total maximum overburden for the tunnel is approximately $322 \mathrm{~m}$. Note that the total overburden thickness along the cross section generally increases to the northeast, and that the total overburden thickness is comprised of the sum of one or more rock units. The calculated vertical thicknesses of the overlying rock units range as follows: 
- Tof unit -0 to $124 \mathrm{~m}$

- $\quad$ To unit -0 to $98 \mathrm{~m}$

- Tor unit -0 to $83 \mathrm{~m}$

- Tvr unit -0 to $156 \mathrm{~m}$

- Tm unit -0 to $102 \mathrm{~m}$

The tunnel excavation distances through each unit can also be determined from the cross section (Figure 2). These tunneling estimates are as follows:

- $\quad$ Tof unit $-518 \mathrm{~m}$

- $\quad$ To unit $-185 \mathrm{~m}$

- $\quad$ Tor unit $-148 \mathrm{~m}$

Note that the entire length of the tunnel excavation is predicted to lie entirely within the Obispo Formation.

\subsection{Field site-Diablo Canyon, San Luis Obispo County, CA}

\subsubsection{Rock units}

The primary rock formation of interest for the tunnel excavation is the Obispo Formation, which is predicted to be the only rock unit that will be encountered along the proposed tunnel trajectory. Brief descriptions of the other rock units encountered in the cross section (the Tertiary basalt/diabase unit and the Monterey Formation) are also presented. These summaries are based on previous studies by Hall (1973), Hall et al. (1979), William Lettis and Associates (2001a, b, c), and observations made from samples collected during the Dec. 3, 2003, field visit.

Obispo Formation (To, Tof and Tor): The Obispo Formation consists of marine and volcaniclastic sedimentary rocks. Exposures of the Obispo formation at Diablo Canyon have been divided by William Lettis and Associates (2001a) into three units: (1) a thick to massively bedded diatomaceous siltstone and tuffaceous sandstone, (2) a medium to thickly bedded dolomite and dolomitic siltstone and sandstone, and (3) a thin to medium- 
bedded extensively sheared shale, siltstone, and claystone. Outcrops along Dry Canyon consist of fine to medium-grained bedded dolomitic sandstone near the proposed tunnel portal. Intercalated dolomitic siltstone, tuffaceous siltsone, porcelanite, chert, and organic-rich siliceous shales were also encountered in this formation. Measured bedding orientations for this area have strikes ranging from $\mathrm{N} 65 \mathrm{~W}$ to $\mathrm{N} 84 \mathrm{~W}$ and dips varying from $32 \mathrm{SW}$ to $55 \mathrm{NE}$. The fold axis orientations of small-scale features are consistent with that of the Pismo Syncline.

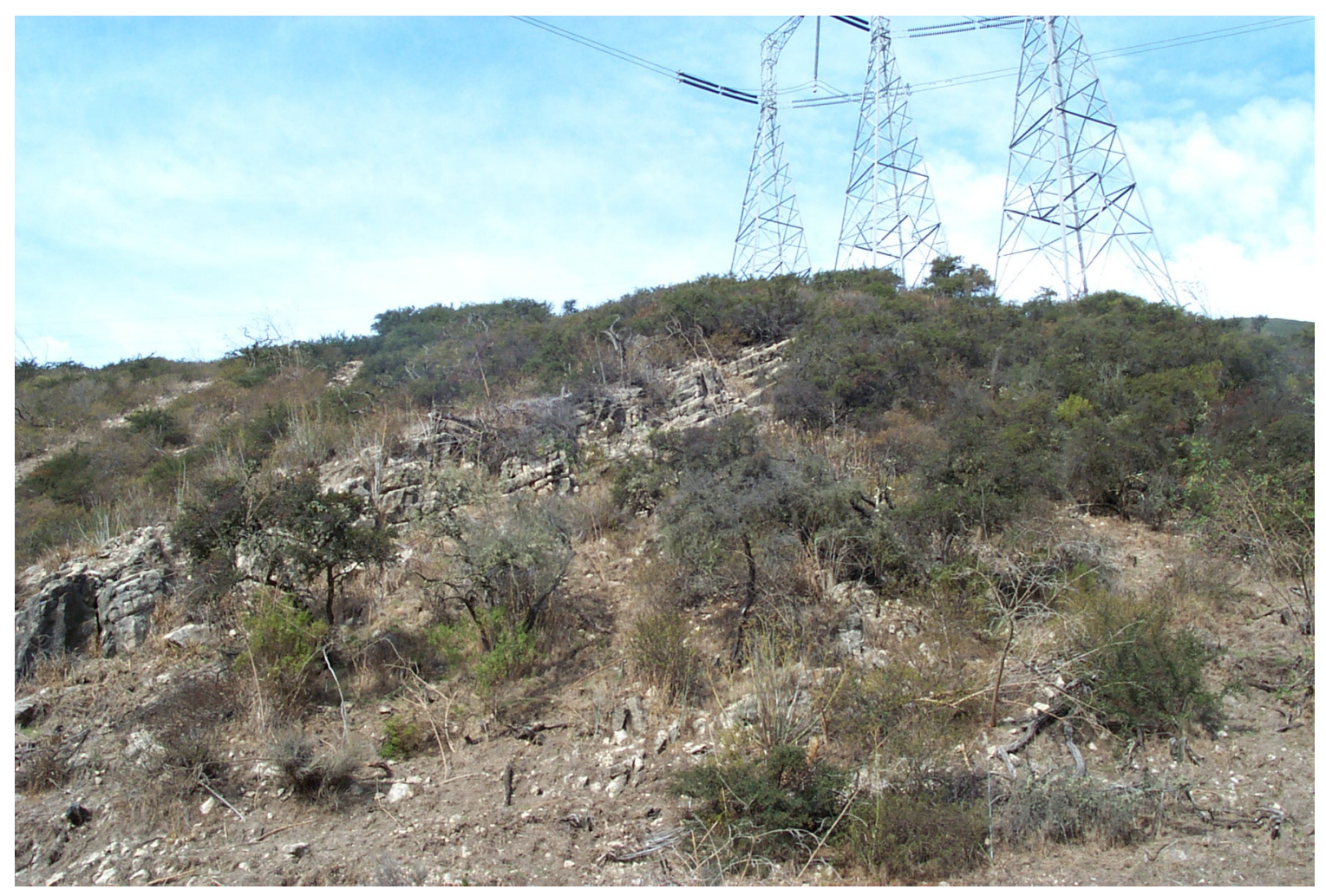

Figure 4. Bedded dolomitic sandstones of the Obispo Formation near the proposed tunnel portal. Transmission line towers are located just above the portal area.

Tertiary Volcanic Rocks (Tvr): This unit is described by Hall et al. (1979) as consisting of greenish-gray to black diabase, occurring as dikes, sills, and flows. Most outcrops have undergone significant spheroidal weathering and alteration (Figure 5), but this rock unit is expected to be more massive and less altered below the weathering horizon in the subsurface. 


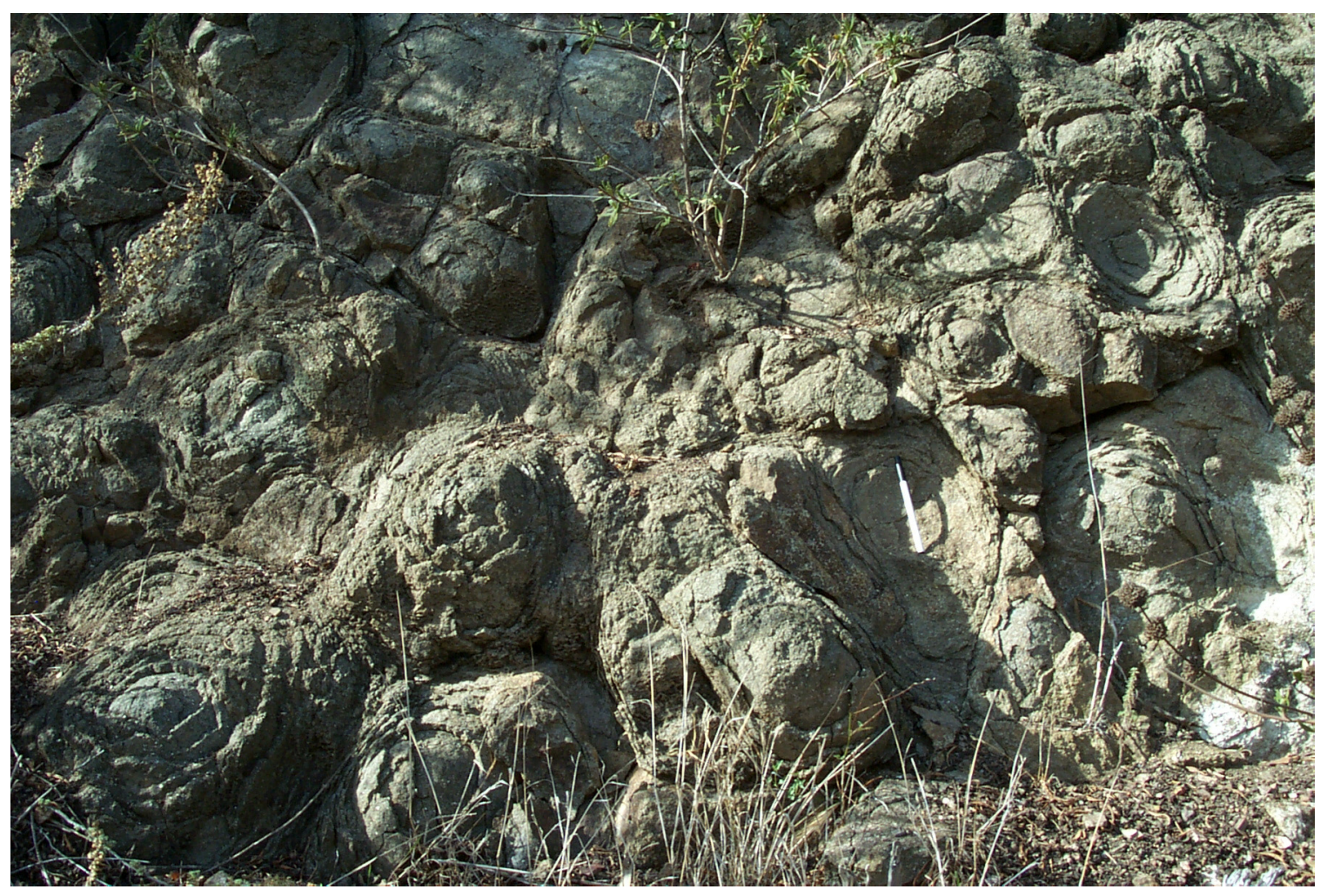

Figure 5: Spheroidal weathering of diabase from an outcrop (sample location DC1203$03)$ in upper Dry Canyon. A pen $(\sim 15 \mathrm{~cm})$ is shown for scale.

Monterey Formation (Tm): The Monterey Formation in the Diablo Canyon area is a diverse assemblage of siliceous marine sediments, consisting of siliceous shales and sandstones, porcelanite, chert, dolostone, and organic-rich phosphatic shales (Schwalbach and Bohacs, 1992). The porosity and density of these sediments is quite variable, depending on the degree of diagenesis that the siliceous rocks have undergone (Chaika and Dvorkin, 2000). The subunit of the Monterey encountered along the northeastern portion of the cross section (Tm) is described by Hall (1973) as consisting of hard siliceous shale and interbeded chert, with beds commonly $0.5-1.0$ inches thick. The unit is typically white and brown to gray in color, and is commonly fractured and sheared. An example of this unit (as encountered in outcrops along Crowbar Canyon) is shown in Figure 6. 


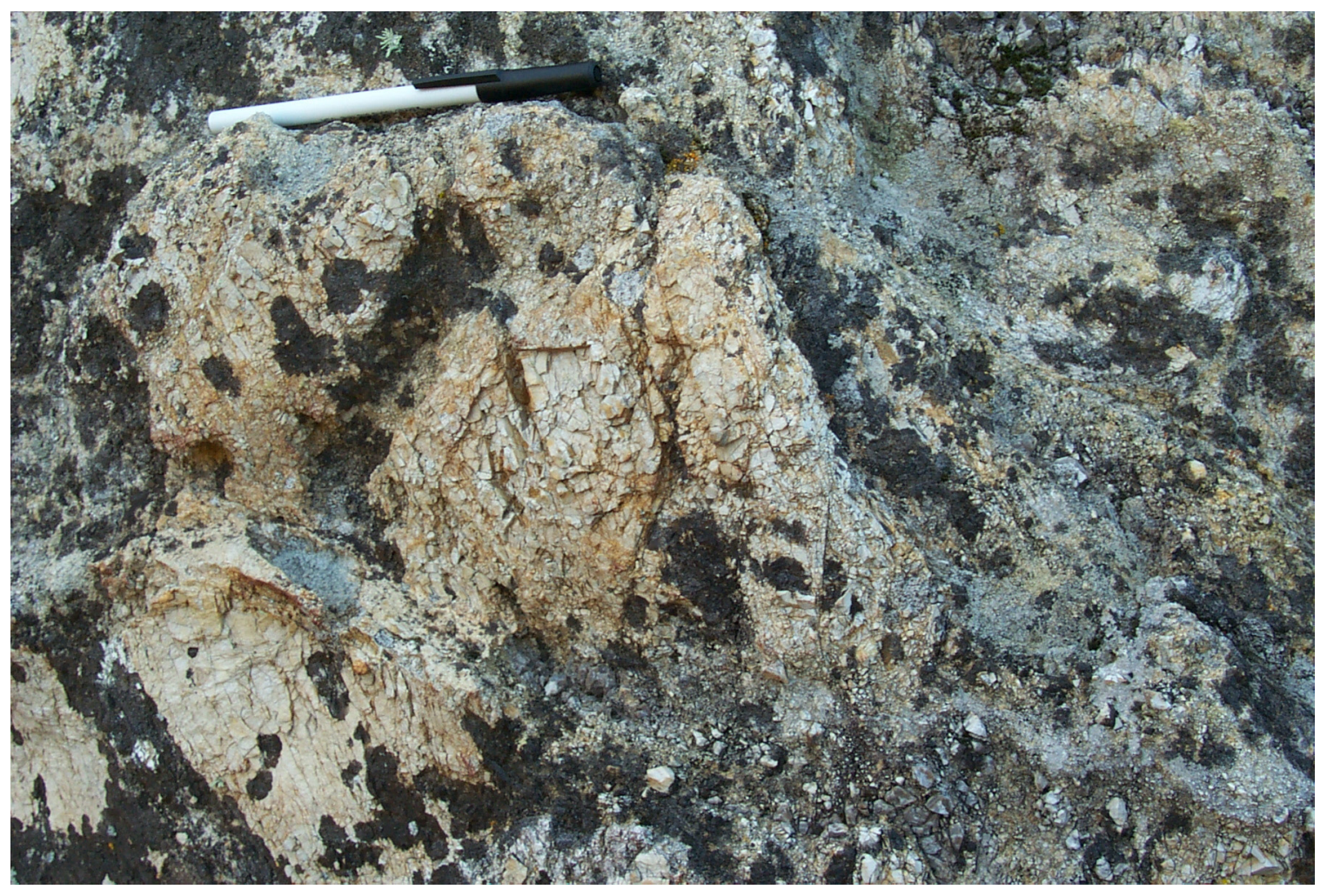

Figure 6. Outcrop of brittle porcelanite from Monterey Formation outcrops (sample location DC1203-09) along Crowbar Canyon. A pen $(\sim 15 \mathrm{~cm})$ is shown for scale.

\subsubsection{Structural features}

Diablo Canyon is located on the southern part of the San Luis/Pismo structural block. The block is bounded on the northeast by the Los Osos Fault zone, on the southwest by a diffuse zone of minor faults, and on the west-northwest by the Hosgri Fault zone. The most prominent regional structural feature is the northwest-trending Pismo syncline, in which the youngest unit (the Pismo Formation) is exposed in the core of the syncline, and the oldest unit (the Obispo Formation) is exposed at the limbs. All of the Plio-Miocene units have undergone significant folding and faulting subsequent to their deposition. Folding is present as both large-scale $(\mathrm{km})$ and small-scale $(\mathrm{m})$ features. There are no map-scale faults in the immediate vicinity of the proposed tunnel location, but it is expected that minor faults will be encountered during the tunneling. The main fault in the Diablo Canyon area is the Hosgri Fault; a NW-trending right-lateral high-angle fault located about $5 \mathrm{~km}$ offshore from the Diablo Canyon power plant. Other identified faults 
in the area include the San Miguelito, Edna, and Pismo Faults, which also have a NW-SE orientation.

\subsection{Rock property measurements}

A limited number of rock property measurements have been conducted on surface samples collected during the visit to Diablo Canyon, as shown in Table 1. Sample DC1203-07 and DC1203-09 were not tested due to the small size and degree of weathering.

Table 1. List of samples and measurements performed

\begin{tabular}{|c|c|c|c|}
\hline Sample ID & GPS $^{1}$ & Description & Tests $^{2}$ \\
\hline DC1203-01 & $\begin{array}{l}\text { East 10S0696193E } \\
\text { North } 3898447 \mathrm{~N}\end{array}$ & $\begin{array}{l}\text { Brown to light brown, fine } \\
\text { grained dolomitic sandstone }\end{array}$ & $\mathrm{PL}, \mathrm{XRD}, \rho, \phi, \mathrm{Vs}, \mathrm{Vp}, \mathrm{UC}$ \\
\hline DC1203-02 & $\begin{array}{l}\text { East 10S0696029E } \\
\text { North } 3899218 \mathrm{~N}\end{array}$ & $\begin{array}{c}\text { Light brown medium } \\
\text { grained dolomitic sandstone }\end{array}$ & $\mathrm{PL}, \mathrm{XRD}, \rho, \phi, \mathrm{Vs}, \mathrm{Vp}, \mathrm{UC}$ \\
\hline DC1203-03 & $\begin{array}{l}\text { East 10S0696031E } \\
\text { North } \quad 3899628 \mathrm{~N}\end{array}$ & Dark gray diabase & $\mathrm{PL}, \mathrm{XRD}, \mathrm{GRS}, \rho, \phi, \mathrm{Vs}, \mathrm{Vp}, \mathrm{UC}$ \\
\hline DC1203-04 & N/A & $\begin{array}{l}\text { Light brown fine grained } \\
\text { dolomitic sandstone }\end{array}$ & $\mathrm{PL}, \rho, \phi, \mathrm{Vs}, \mathrm{Vp}, \mathrm{UC}$ \\
\hline DC1203-05 & $\begin{array}{l}\text { East 10S0696232E } \\
\text { North } 3899785 \mathrm{~N}\end{array}$ & $\begin{array}{c}\text { Light brown dolomitic } \\
\text { siltstone }\end{array}$ & $\mathrm{PL}, \rho, \phi, \mathrm{Vs}, \mathrm{Vp}, \mathrm{UC}$ \\
\hline DC1203-06 & $\mathrm{N} / \mathrm{A}$ & Black chert & PL, XRD, GRS, $\rho, \phi$, Vs, Vp, UC \\
\hline DC1203-07 & $\mathrm{N} / \mathrm{A}$ & Organic shale & Not tested \\
\hline DC1203-08 & N/A & Light gray to gray tuff & $\mathrm{PL}, \rho, \phi, \mathrm{Vs}, \mathrm{Vp}, \mathrm{UC}$ \\
\hline DC1203-09 & $\begin{array}{l}\text { East 10S0694973E } \\
\text { North } 3900320 \mathrm{~N}\end{array}$ & $\begin{array}{l}\text { Weathered and friable } \\
\text { porcelanite }\end{array}$ & Not tested \\
\hline DC1203-10 & $\mathrm{N} / \mathrm{A}$ & Pale yellow porcelanite & PL, GRS, $\rho, \phi$, Vs, Vp, UC \\
\hline DC1203-11 & $\begin{array}{l}\text { East 10S0695581E } \\
\text { North } 3897814 \mathrm{~N}\end{array}$ & $\begin{array}{c}\text { Poorly cemented } \\
\text { volcaniclastic sandstone }\end{array}$ & $\mathrm{PL}, \mathrm{GRS}, \rho, \phi, \mathrm{Vs}, \mathrm{Vp}, \mathrm{UC}$ \\
\hline
\end{tabular}

${ }^{1}$ GPS data reported using UTM coordinate system.

${ }^{2} \mathrm{PL}=$ Point Load Test, XRD = X-Ray Diffraction, GRS = Gamma-Ray Spectrometry, $\rho=$ Density, $\phi=$ Porosity, $\mathrm{Vs}=\mathrm{S}$-wave Velocity, $\mathrm{Vp}=\mathrm{P}$-wave Velocity, $\mathrm{UC}=$ Unconfined Compression Test 


\subsubsection{X-ray diffraction analysis}

A subset of the samples collected during the field visit was analyzed at the UC Berkeley, Department of Chemistry using x-ray diffraction to characterize their bulk mineralogy.

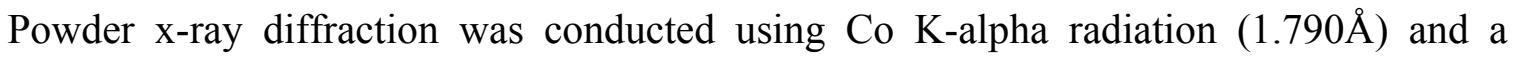
Bruker general area detector. The instrument resolution is $0.05^{\circ}$ in 2 theta, and the analysis time for each sample was 10 minutes. XRD samples were measured by depositing a powdered aliquot of sample on a quartz plate.

Two samples of dolomitic sandstone from the Obispo Formation contained dolomite and quartz as their primary minerals, while a sample of chert from the Obispo Formation contained only quartz. The diabase sample contained plagioclase and pyroxene, and did not contain any quartz (Appendix 1).

\subsubsection{Gamma-ray spectrometric analysis}

Gamma ray spectrometric analysis was performed on four samples to identify the level of naturally occurring radioactivity in rocks from the Diablo Canyon area. The samples were analyzed at the Berkeley Low Background Facility (LBF) using Cs-137 gamma-ray sources. Radionuclide concentrations have been obtained from these spectra by comparison to spectra from standard (calibration) materials. The standards consisted of gamma-sources and reference materials that are traceable to International Atomic Energy Agency (IAEA) gamma-ray standards, CP grade (chemically pure) chemicals (for potassium), or $\mathrm{U}$ and Th assay standards from the New Brunswick Laboratory of the US Atomic Energy Commission (AEC). In this procedure, we first determined the intensities for peaks characteristic of each radionuclide present in a sample. These peak intensities are then translated into absolute elemental abundance or radionuclide activity through comparisons with intensities of the same peaks in the standard calibration samples.

Results are shown in Table 2. The $\mathrm{U}, \mathrm{Th}$, and $\mathrm{K}$ values are reported as mass concentrations: $\mathrm{U}$ and $\mathrm{Th}$ in parts per million (ppm), and $\mathrm{K}$ in percent (\%). Numbers in 
parentheses represent single standard deviations of the listed values, based on counting statistics alone.

Table 2. Summary of gamma-ray spectrometry results

\begin{tabular}{|c|c|c|c|c|c|}
\hline Sample ID & Lithology & Rock Unit & $\begin{array}{c}\text { Uranium } \\
\mathbf{p p m}\end{array}$ & $\begin{array}{c}\text { Thorium } \\
\mathbf{p p m}\end{array}$ & $\begin{array}{c}\text { Potassium } \\
\mathbf{\%}\end{array}$ \\
\hline DC1203-03 & Diabase & Tvr & $1.33(0.04)$ & $4.36(0.09)$ & $1.87(0.01)$ \\
\hline DC1203-06 & Black chert & Tm & $2.28(0.03)$ & $1.15(0.03)$ & $0.29(0.02)$ \\
\hline DC1203-10 & Porcelanite & Tm & $2.18(0.05)$ & $0.57(0.05)$ & $0.120(0.04)$ \\
\hline DC1203-11 & $\begin{array}{c}\text { Volcaniclastic } \\
\text { sandstone }\end{array}$ & Tof & $3.32(0.03)$ & $9.67(0.06)$ & $3.92(0.01)$ \\
\hline
\end{tabular}

The gamma-ray spectrometry results for the Monterey Formation samples (DC 1203-06 and DC 1203-10) are consistent with previously published analyses for similar samples from outcrops at nearby Shell Beach and Point Bushon (Schawalbach and Bohacs, 1992). Cherts and porcelinite are usually low in both $T h$ and $\mathrm{K}$ relative to $\mathrm{U}$, because of their siliceous composition. The diabase sample also has low concentrations of $\mathrm{U}, \mathrm{Th}$, and $\mathrm{K}$, as would be expected in mafic rocks. The tuffaceous sandstone has $\mathrm{U}, \mathrm{Th}$, and $\mathrm{K}$ concentrations within the range of typical rhyolite (Wollenberg and Smith, 1990).

\subsubsection{Grain density and porosity}

The grain density and porosity of samples collected during the field survey were determined by the gas displacement-Boyle's law method using helium. The tool used for this measurement is helium pycnometer, which is specifically designed to measure sample volume and to provide the necessary information to calculate the density and porosity. To use the apparatus available at LBNL, the samples were cored to 1-inch (2.54 $\mathrm{cm}$ ) diameter and oven dried at $90^{\circ} \mathrm{C}$ for 24 hours. The samples were weighed prior to the measurement.

Calibration was performed using inserts of known volume to determine the volumepressure relationship, which was used to calculate the grain volume of the samples. The 
applied helium pressure was $80 \mathrm{psi}$. High-precision digital pressure gauges were used to monitor and control the pressure in the helium pycnometer.

The density was calculated using the grain volume and sample weight measurements, and were repeated to evaluate reproducibility of measurements. The reliability of sample measurements can also be evaluated by the grain density measurement at sample DC1203-06, determined as pure quartz by XRD analysis. The measured grain density value $(2.59 \mathrm{~g} / \mathrm{cc})$ is within $2.5 \%$ of the actual grain density of quartz $(2.65 \mathrm{~g} / \mathrm{cc})$. The porosity was determined using estimated average bulk volumes of the sample and the measured grain volume. The bulk volume was calculated using sample diameter and length of the core plugs. Table 3 summarizes the density and porosity results.

Table 3. Summary of density and porosity measurements

\begin{tabular}{|l|c|c|c|c|c|c|c|c|}
\hline Sample ID & Diameter* & Length* & $\begin{array}{c}\text { Bulk } \\
\text { Volume } \\
\mathbf{c m}\end{array}$ & $\begin{array}{c}\text { Grain } \\
\text { Volume } \\
\mathbf{c m}\end{array}$ & $\begin{array}{c}\text { Weight } \\
\mathbf{c c}\end{array}$ & $\begin{array}{c}\text { Bulk } \\
\text { Density } \\
\text { g/cc }\end{array}$ & $\begin{array}{c}\text { Grain } \\
\text { Density } \\
\text { g/cc }\end{array}$ & Porosity \\
\hline DC1203-01 & 2.513 & 4.87 & 24.14 & 19.77 & 56.05 & 2.32 & 2.84 & 22.0 \\
\hline DC1203-02 & 2.507 & 9.22 & 45.49 & 32.24 & 101.90 & 2.24 & 2.81 & 25.5 \\
\hline DC1203-03 & 2.537 & 5.77 & 29.17 & 27.90 & 74.90 & 2.57 & 2.68 & 4.54 \\
\hline DC1203-04 & 2.538 & 4.22 & 21.34 & 18.34 & 52.29 & 2.45 & 2.86 & 13.07 \\
\hline DC1203-05 & $2.351^{* *}$ & 2.95 & 12.79 & 10.27 & 28.94 & 2.26 & 2.82 & 24.48 \\
\hline DC1203-06 & 2.527 & 4.32 & 21.66 & 21.25 & 54.97 & 2.54 & 2.59 & 1.94 \\
\hline DC1203-08 & 2.513 & 3.55 & 14.92 & 12.27 & 32.31 & 2.17 & 2.63 & 2.63 \\
\hline DC1203-10 & 2.52 & 2.63 & 13.09 & 7.78 & 18.46 & 1.41 & 2.37 & 68.5 \\
\hline DC1203-11 & 2.491 & 2.30 & 22.45 & 18.28 & 48.00 & 2.14 & 2.62 & 22.8 \\
\hline
\end{tabular}

* Average value measured using micrometer

** Sample with missing volume along its axis

The overall density and porosity results from the helium pycnometer measurement are within the range of values reported by Willian Lettis and Associates (2001c), Isaacs (1981), and Chaika and Dvorkin (2000). However, porosity results may be a little high, owing to weathering and the presence of joints and fractures (as observed in the diabase, volcaniclastic sandstone, and porcelanite samples). The bulk density of the porcelanite is 
consistent with density values described by Isaacs (1981) and Chaika and Dvorkin (2000). The density of dolomitic sandstone is slightly higher than subsurface samples described by William Lettis and Associates (2001c). Variations in the composition, grain size, pore size, degree of weathering and cementation can affect the density and porosity of dolomitic sandstones.

\subsubsection{Rock elastic moduli (dynamic) and strength measurement}

Engineering rock testing was performed on a variety of samples collected from the Diablo Canyon area. The point load test was conducted in the UC Berkeley Engineering Department laboratory of Prof. Steven Glaser. Unconfined compressive and ultrasonic tests were conducted at LBNL. Properties measured in the laboratory were used to characterize the strength and elastic properties of rocks close to the potential tunnel.

The ultrasonic tests measure compressional and shear wave velocities in dry rocks assuming isotropic rock. Measurements were performed in core samples with 1-inch $(2.54 \mathrm{~cm})$ diameter and various lengths (Table 4). The method consists of propagating ultrasonic pulses through a rock sample and then measuring the travel time to determine the velocity using a relationship [velocity] $=[$ sample length]/[travel time through sample]. However, since the measured travel time includes the system delay time due to wave propagation within the ultrasonic transducers (between a pair of piezoelectric elements), this has to be subtracted from the measured travel time. The system delay time was determined by measuring the wave travel time between a pair of transducers without a sample. The measurements were conducted using both compressional and shear wave transducers with main frequencies of $1 \mathrm{MHz}$ and $500 \mathrm{kHz}$. The propagation velocity of waves in a specimen is influenced by different material parameters such as stiffness, density and microstructural features.

Poisson's ratio computed from compressional (Vp) and shear velocities (Vs) indicates the distribution of pore space resulting from grain geometry and the presence of fractures. The Poisson's ratio $(v)$ is determined using the relationship: 


$$
v=\frac{2-g}{2(1-g)}
$$

where

$$
g \equiv\left(\frac{V p}{V S}\right)^{2}
$$

and where $\mathrm{Vp}$ and $\mathrm{Vs}$ are the measured $\mathrm{P}$ and $\mathrm{S}$ wave velocities

Shear modulus (G) and Young's modulus (E) are related to the wave velocity and Poisson's ratio through:

$$
\begin{aligned}
V s=\sqrt{\frac{G}{\rho}} & =\sqrt{\frac{E}{2 \rho(1+v)}} \\
E & =2 G(1+v)
\end{aligned}
$$

where $\rho$ is the rock density.

The acoustic measurement provides input for the petrophysical characteristics of in situ material (e.g. weathering and fracturing reduces wave velocity and amplitude), which would be important for preliminary evaluation of the site for tunnel construction. 
Table 4. Summary of ultrasonic velocity results

\begin{tabular}{|c|c|c|c|c|c|c|c|}
\hline Sample ID & Length & $\begin{array}{c}\text { wave } \\
\text { wave }\end{array}$ & $\begin{array}{c}\text { Poisson's } \\
\text { Ratio }\end{array}$ & $\begin{array}{c}\text { Bulk } \\
\text { Density }\end{array}$ & $\begin{array}{c}\text { Shear } \\
\text { modulus }\end{array}$ & $\begin{array}{c}\text { Young's } \\
\text { modulus }\end{array}$ \\
\hline cm & $\mathbf{m} / \mathbf{s}$ & $\mathbf{m} / \mathbf{s}$ & & $\mathbf{k g} / \mathbf{m}^{3}$ & $\mathbf{G P a}$ & $\mathbf{G P a}$ \\
\hline DC1203-01bedding & 4.868 & 3915 & N/A & N/A & N/A & N/A & N/a \\
\hline DC1203-02a & 4.348 & 2210 & 3657 & 0.212 & 2240 & 10.9 & 27 \\
\hline DC1203-02b & 4.059 & 2308 & 3826 & 0.214 & 2240 & 11.9 & 29 \\
\hline DC1203-03 & 5.89 & 2493 & 4100 & 0.21 & 2568 & 43.2 & 104 \\
\hline DC1203-04bedding & 4.218 & 4218 & N/A & N/A & N/A & N/A & N/A \\
\hline DC1203-04orthog. & 4.218 & 3087 & 5043 & $0.21^{*}$ & 2450 & 62.3 & 151 \\
\hline DC1203-05 & 3.03 & 2353 & 3743 & 0.173 & 2263 & 31.7 & 74 \\
\hline DC1203-06 & 4.319 & 3634 & 5471 & 0.105 & 2537 & 75.9 & 168 \\
\hline DC1203-08 & 3.551 & 1940 & 3129 & 0.187 & 2165 & 21.2 & 50 \\
\hline DC1203-10 & 2.625 & 1982 & 2182 & $0.0017^{* *}$ & 1410 & 6.7 & N/A \\
\hline DC1203-11b & 2.228 & 1626 & 2864 & 0.262 & 2138 & 17.5 & 44 \\
\hline
\end{tabular}

* Uses the average $\mathrm{S}$ wave velocities for two orthogonal measurements

** Presence of pre-existing joints and fractures

Unconfined compression tests were performed using a displacement-controlled loading device. A Teflon film was inserted on both ends of samples to reduce the friction between the sample and the load cell. As a result, the actual loading rate on the sample was not constant, owing to the plastic deformation in the Teflon film. Calibration of the load cell was performed using a dead-weight tester. The nonlinearity and hysteresis of the load cell was not significant for our measurements. The results of unconfined compressive strength tests are summarized in Table 5. 
Table 5. Summary of unconfined compression test results

\begin{tabular}{|c|c|c|c|c|c|}
\hline Sample ID & Description & $\begin{array}{l}\text { Rock } \\
\text { Unit }\end{array}$ & Feature in Sample & $\begin{array}{c}\text { Failure } \\
\text { Mode }\end{array}$ & $\begin{array}{c}\text { Strength } \\
\text { (MPa) }\end{array}$ \\
\hline DC1203-01 & $\begin{array}{c}\text { Brown to light } \\
\text { brown, fine grained } \\
\text { dolomitic sandstone }\end{array}$ & $\mathrm{Tmb}$ & $\begin{array}{c}\text { Bedding parallel to } \\
\text { sample axis }\end{array}$ & $\begin{array}{c}\text { Extensile } \\
\text { failure } 20^{\circ} \\
\text { from bedding }\end{array}$ & 124 \\
\hline DC1203-02 & $\begin{array}{c}\text { Light brown } \\
\text { medium grained } \\
\text { dolomitic sandstone }\end{array}$ & Tof & $\begin{array}{c}\text { No discernible } \\
\text { features }\end{array}$ & $\begin{array}{l}\text { Extensile } \\
\text { failure }\end{array}$ & 31 \\
\hline DC1203-03 & Gabbro & Tvr & $\begin{array}{c}\text { No discernible } \\
\text { features }\end{array}$ & $\begin{array}{c}\text { Extensile } \\
\text { failure }\end{array}$ & 79 \\
\hline DC1203-04 & $\begin{array}{l}\text { Light brown fine } \\
\text { grained dolomitic } \\
\text { sandstone }\end{array}$ & To & $\begin{array}{c}\text { Tip on one end and } \\
\text { one healed joint on } \\
\text { other end }\end{array}$ & $\begin{array}{c}\text { Extensile } \\
\text { failure along } \\
\text { existing } \\
\text { fractures }\end{array}$ & 116 \\
\hline DC1203-05* & $\begin{array}{c}\text { Light brown } \\
\text { dolomitic siltstone }\end{array}$ & $\mathrm{Tm}$ & $\begin{array}{c}\text { Several healed and } \\
\text { partially healed } \\
\text { joints }\end{array}$ & $\begin{array}{c}\text { Extensile } \\
\text { failure along } \\
\text { existing } \\
\text { fractures }\end{array}$ & 41 \\
\hline DC1203-06 & Black chert & $\mathrm{Tm}$ & $\begin{array}{c}\text { No discernible } \\
\text { features }\end{array}$ & $\begin{array}{c}\text { Extensile } \\
\text { failure }\end{array}$ & 179 \\
\hline DC1203-08 & $\begin{array}{l}\text { Light gray to gray } \\
\text { tuff }\end{array}$ & $\mathrm{Tm}$ & $\begin{array}{c}\text { Bedding parallel to } \\
\text { sample axis }\end{array}$ & $\begin{array}{c}\text { Extensile } \\
\text { failure along } \\
\text { bedding }\end{array}$ & 48 \\
\hline DC1203-10 & $\begin{array}{l}\text { Pale yellow } \\
\text { porcelanite }\end{array}$ & $\mathrm{Tm}$ & $\begin{array}{c}\text { Several healed and } \\
\text { partially healed } \\
\text { joints }\end{array}$ & $\begin{array}{c}\text { Extensile } \\
\text { failure along } \\
\text { existing } \\
\text { fractures }\end{array}$ & 23 \\
\hline DC1203-11 & $\begin{array}{c}\text { Poorly cemented } \\
\text { volcaniclastic } \\
\text { sandstone }\end{array}$ & Tof & $\begin{array}{c}\text { Highly } \\
\text { heterogeneous, } \\
\text { friable and } \\
\text { weathered }\end{array}$ & $\begin{array}{l}\text { Extensile } \\
\text { failure }\end{array}$ & 26 \\
\hline
\end{tabular}

* Sample with partially missing mass 
The point load test provides an indirect estimate for the uniaxial compressive strength of the rock, taking into account the sample geometry. In this case, several measurements using irregular shaped pieces of the same material were averaged to provide a rough estimate of the compressive strength. Because of the restricted amount of sample material available, some measurements were made using only one sample (Table 6 and Figure 7).

Table 6. Summary of Point Load Test

\begin{tabular}{|c|c|c|}
\hline $\begin{array}{c}\text { Sample } \\
\text { ID }\end{array}$ & $\begin{array}{c}\text { Number of } \\
\text { Measurements }\end{array}$ & $\begin{array}{c}\text { Average Compressive } \\
\text { Strength (MPa) }\end{array}$ \\
\hline DC1203-01* & 9 & 205 \\
\hline DC1203-01** & 5 & 178 \\
\hline DC1203-02 & 9 & 43 \\
\hline DC1203-03 & 1 & 58 \\
\hline DC1203-04 & 9 & 207 \\
\hline DC1203-05 & 1 & 93 \\
\hline DC1203-06 & 7 & 219 \\
\hline DC1203-08* & 4 & 64 \\
\hline DC1203-08** & 4 & 64 \\
\hline DC1203-10 & 4 & 30 \\
\hline DC1203-11 & 1 & \\
\hline
\end{tabular}

* Point load applied perpendicular to bedding

** Point load applied parallel to bedding 


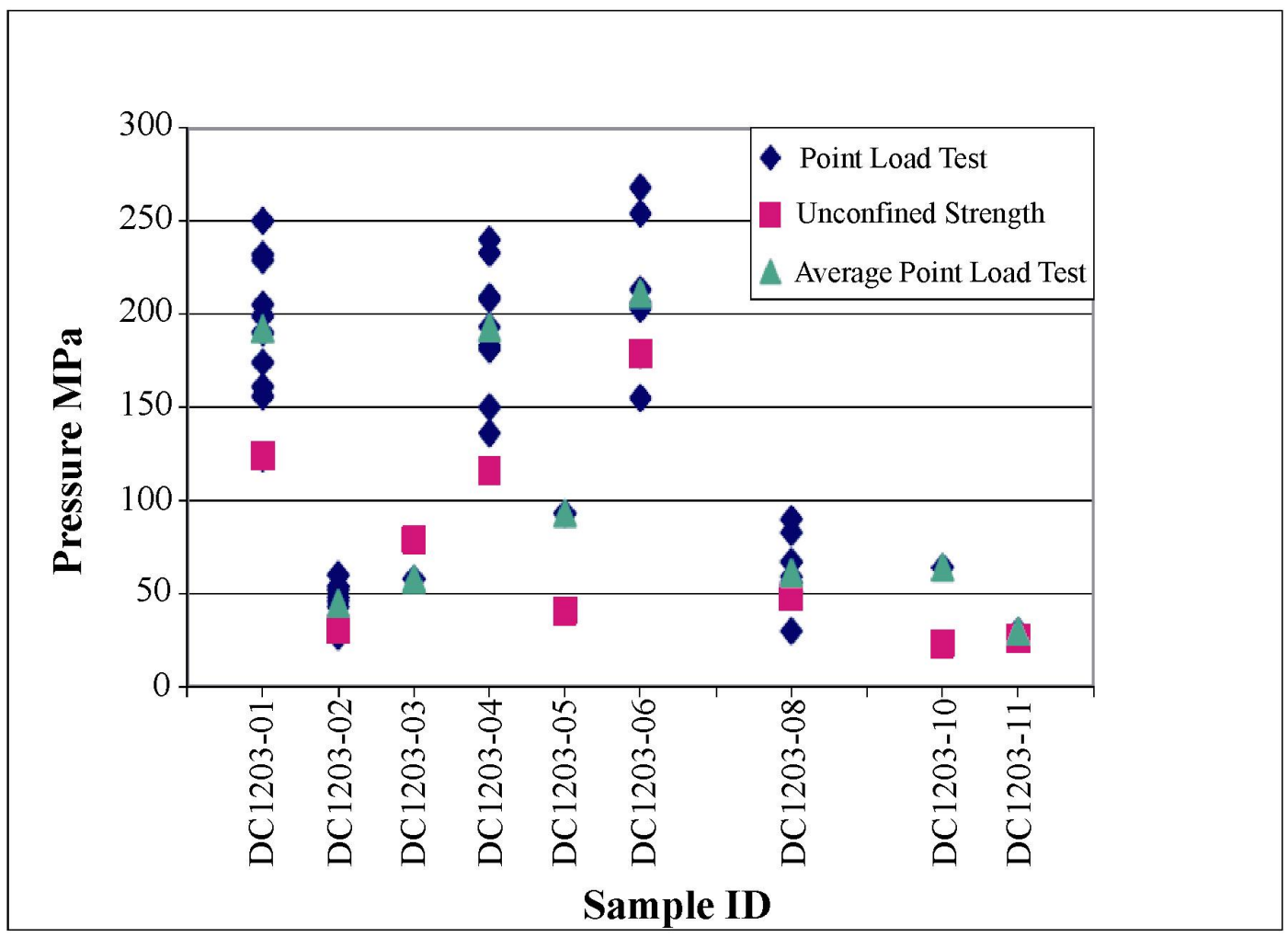

Figure 7. Graph comparing results of point load and unconfined compressive strength tests

The average compressive strength values obtained from the point-load measurements range from 30 to $219 \mathrm{MPa}$ (Table 5). These values give relative rock strength, as the measurements were performed using irregularly shaped rock samples. Unconfined compression tests conducted on the same types of rocks samples yielded compressive strength values ranging from 23 to $179 \mathrm{MPa}$ (Table 4). In general, the compressive strength values obtained from the point-load tests were larger compared to the results from the uniaxial compression tests (Figure 7). This may partially result from the irregular sample geometry used for the point-load tests and the occurrence of fractures and joints in the samples used for the uniaxial compression test. These results give a relative strength value for the surface samples. Variation in the results from the two methods is a function of the accuracy of measurements and the quality of the rock sample. It is expected that in the subsurface the rock strength would be higher than the results obtained from outcrops. However, results from unconfined compressive tests conducted 
by PG\&E on borehole samples of dolomitic sandstone, dolomitic siltstone to friable dolomite, and sandstone from the Independent Spent Fuel Storage Installation (ISFSI) area, range from 1 to $71 \mathrm{MPa}$ (William Lettis and Associates, 2001c). Discrepancy between our results and from the ISFSI might be due to sample quality, presence of clay minerals, and presence of water.

\section{Geologic Hazards}

In the Diablo Canyon area, there are a variety of geologic hazards and issues associated with the construction of a tunnel and maintenance of a neutrino detector facility. These issues are discussed below:

\subsection{Landslide}

A number of Quaternary and active landslides have been previously identified in the Diablo Canyon area (Figure 1). A large active landslide is located along the southern flanks of Diablo Canyon. No active landslides were observed along the northern side of Diablo Canyon in the vicinity of the proposed tunnel location. However, with the steep topography in the area around the proposed western portal, care must be taken to ensure that surface ground failure is not triggered by construction activities. Heavy rains, seismic activity, or wildfires in the area could also lead to landslides.

\subsection{Seismic hazards}

The study area is located within a seismically active area. The San Simeon-Hosgri Fault has been identified as a likely source for future seismicity in the vicinity of Diablo Canyon. Recent results from the studies presented by PG\&E (1988) confirmed that Hosgri Fault controls the seismicity in the Diablo Canyon. The dominant displacement on the Hosgri Fault is strike-slip with minor dip-slip component. A magnitude 6.5 earthquake occurred near San Simeon, CA, on Dec. 22, 2003, along a reverse fault (likely the Oceanic fault zone) in the Santa Lucia Mountains (http://neic.usgs.gov/neis/eq_depot/2003/eq_031222/neic_crah_ts.html and http://earthquake.usgs.gov/recenteqsUS/Quakes/nc40148755.htm). Tunnel design and construction work should take such seismic activity into consideration. 


\subsection{Water table}

The main groundwater table beneath the coastal terrace north and south of the plant site is controlled by sea level at the coastline and gradually rises beneath the hills southeast of the plant site. The streams along Diablo Canyon (where the drainage along the lower reaches of the canyon has been significantly modified by engineering activities by PG\&E) and Crowbar Canyon are ephemeral in nature. PG\&E has three water wells located along Diablo Canyon upstream of the $500 \mathrm{kV}$ switchyard. The water level in these wells exhibits seasonal variability, but is typically around $200 \mathrm{ft}$ above sea level, which would place the tunnel above the regional water table (PG\&E, 1988). However, springs along some of the hillsides in the area (Figure 8) indicate the presence of local perched water tables. It should be assumed that the tunnel will be subject to water seepage during excavation.

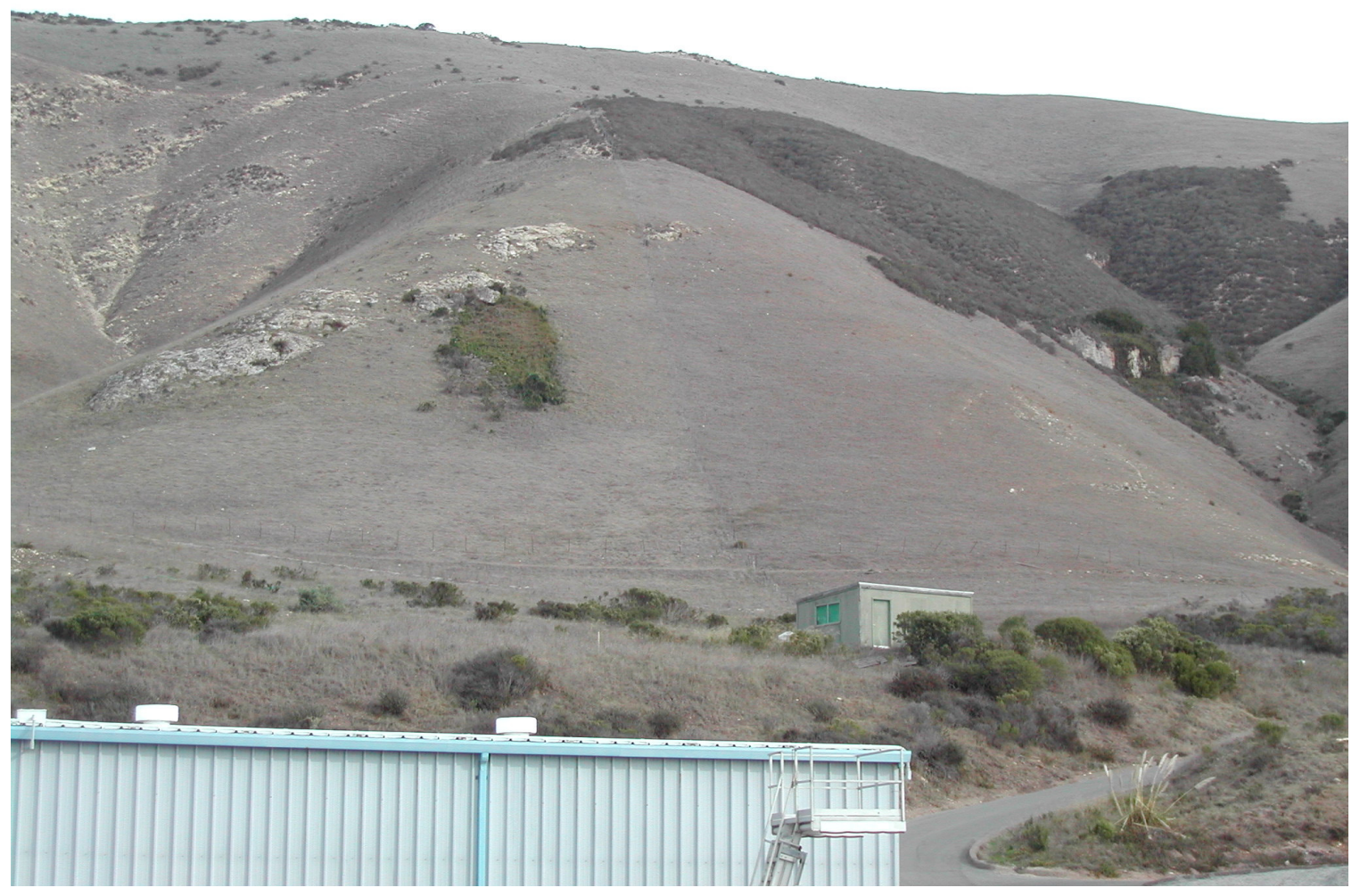

Figure 8. Spring (with zone of vegetation below) issuing from perched water table in the Obispo Formation along hillside above the Diablo Canyon nuclear power plant. 


\subsection{Presence of hydrocarbons}

The Monterey Formation is a major source of hydrocarbons in the nearby Santa Maria Basin. Although the Obispo Formation (the host formation for the current tunnel design) typically has lower concentrations of organic matter than the overlying Monterey Formation, there remains the possibility of encountering elevated hydrocarbon concentrations of gases such as methane during tunnel excavation. Borehole studies will provide more definitive information relating to this potential tunneling hazard.

\subsection{Subsurface temperatures}

There are no surface thermal features in the Diablo Canyon area that would suggest the presence of elevated subsurface temperatures. The tunnel reaches a maximum depth of $308 \mathrm{~m}$ beneath the ground surface. Using a surface ground temperature of $15^{\circ} \mathrm{C}$, a thermal gradient of $25^{\circ} \mathrm{C} / \mathrm{km}$, and a depth of $300 \mathrm{~m}$, a maximum underground temperature of $22.5^{\circ} \mathrm{C}$ was calculated. This temperature would not pose any difficulties to underground construction activities.

\subsection{Swelling clays}

Clay minerals exist only in small amounts in the rock samples collected during the visit to the Diablo Canyon site. However, only more resistant outcrops were sampled, and clay-rich beds would not likely be well exposed in surface outcrops. Thin, intercalated clay beds were identified within the Obispo Formation in trenches and outcrops by William Lettis and Associates (2001a) during their detailed mapping of the ISFSI area, located just south of the proposed tunnel. Similar beds are expected to be found during tunneling.

\section{Summary}

Geological characterization of Diablo Canyon provides a basic understanding of the lithology, structure, physical, and mechanical properties of rocks, and geological hazard issues that would factor into tunnel design and construction activities for the Neutrino Project. Although this preliminary analysis was conducted using surface rock samples, 
which are influenced by weathering, fracturing, and amount of rock material, these values can be used as input for the preliminary estimate of engineering costs. Moreover, tunnel design should consider the geological hazards identified at the Diablo Canyon site.

Acknowledgments. We are grateful to Stuart Freedman and Karsten Heeger for the opportunity to work with the Neutrino Project group. We thank Lloyd Cluff and William Page of PG\&E for sharing the results of their extensive geologic studies of the area and for leading our field visit to Diablo Canyon. We also thank Andrew Mei (LBNL) for sample preparation, Liviu Tomutsa (LBNL), Alan Smith (LBNL), and Yadong Yin (UCB) for their help with laboratory measurements, and Chris Laughton (FermiLab) for his insights on geo-engineering and tunnel design issues. Thanks to Dick Goodman and Tor Brekke for helpful discussions on tunneling. This work was supported by the Berkeley Laboratory Directed Research and Development Program (LDRD) entitled "Designing a Novel Reactor Neutrino Oscillation Experiment for Measuring the Neutrino Mixing Angle $\theta_{13} "$.

\section{References}

Anderson, K. et al. (2004) A New Nuclear Reactor Neutrino Experiment to Measure theta 13. WHITE PAPER REPORT on Using Nuclear Reactors to Search for a value of $\theta 13$. http://arxiv.org/abs/hep-ex/0402041

Chaika, C., and Dvorkin, J. (2000) Porosity reduction during diagenesis of diatomaceous rocks. AAPG Bulletin, v. 84, pp. 1173-1184.

Hall, C.A. (1973) Geologic map of the Morro Bay South and Port San Luis Quadrangles, San Luis Obispo County, California, USGS Misc. Field Studies Map MF-511.

Hall, C.A., Ernest, W.G., Prior, S.W. and Wiese, J.W. (1979) Geologic Map of the San Luis Obispo - San Simeon Region, California. USGS Misc. Invest. Ser. Map I-1097.

Isaacs, C. (1981) Field characterization of rocks in the Monterey Formation along the coast near Santa Barbara, California. In: Guide to the Monterey Formation in the 
California coastal area, Ventura to San Luis Obispo. Pacific Section AAPG. Vol. 52 pp. $39-53$.

Schwalbach, J.R., and Bohacs, K.M. (1992) Field Guide to the Monterey Formation Outcrops at Shell Beach and Point Buchon, Pismo Basin, California. In: Sequence Stratigraphy in Fine-grained Rocks: Examples from the Monterey Formation, eds. Schwalbach, J.R., and Bohacs, K.M., Pacific Section, SEPM, v. 70, pp. 31-46.

Pacific Gas and Electric Company - (PG\&E) (1988) Final Report of the Diablo Canyon Long Term Seismic Program. Docket Nos. 50-275 and 50-323. pp. 1-17.

William Lettis and Associates, Inc. (2001a) Diablo Canyon ISFSI Data Report A, Rev. 1, Geologic Mapping in the Plant Site Area and ISFSI Study Area.

William Lettis and Associates, Inc. (2001b) Diablo Canyon ISFSI Data Report H, Rev. 0, Rock Strength Data and GSI Sheets.

William Lettis and Associates, Inc. (2001c) Diablo Canyon ISFSI Data Report I, Rev. 1, Rock Laboratory Test Data (GeoTest Unlimited).

Wollenberg, H. and Smith, A. (1990) A geochemical assessment of terrestrial gamma-ray absorbed dose rates, Health Physics, vol. 58, no. 2, pp. 183-189. 


\section{Appendix 1}

Results of X-Ray Diffraction Analysis 


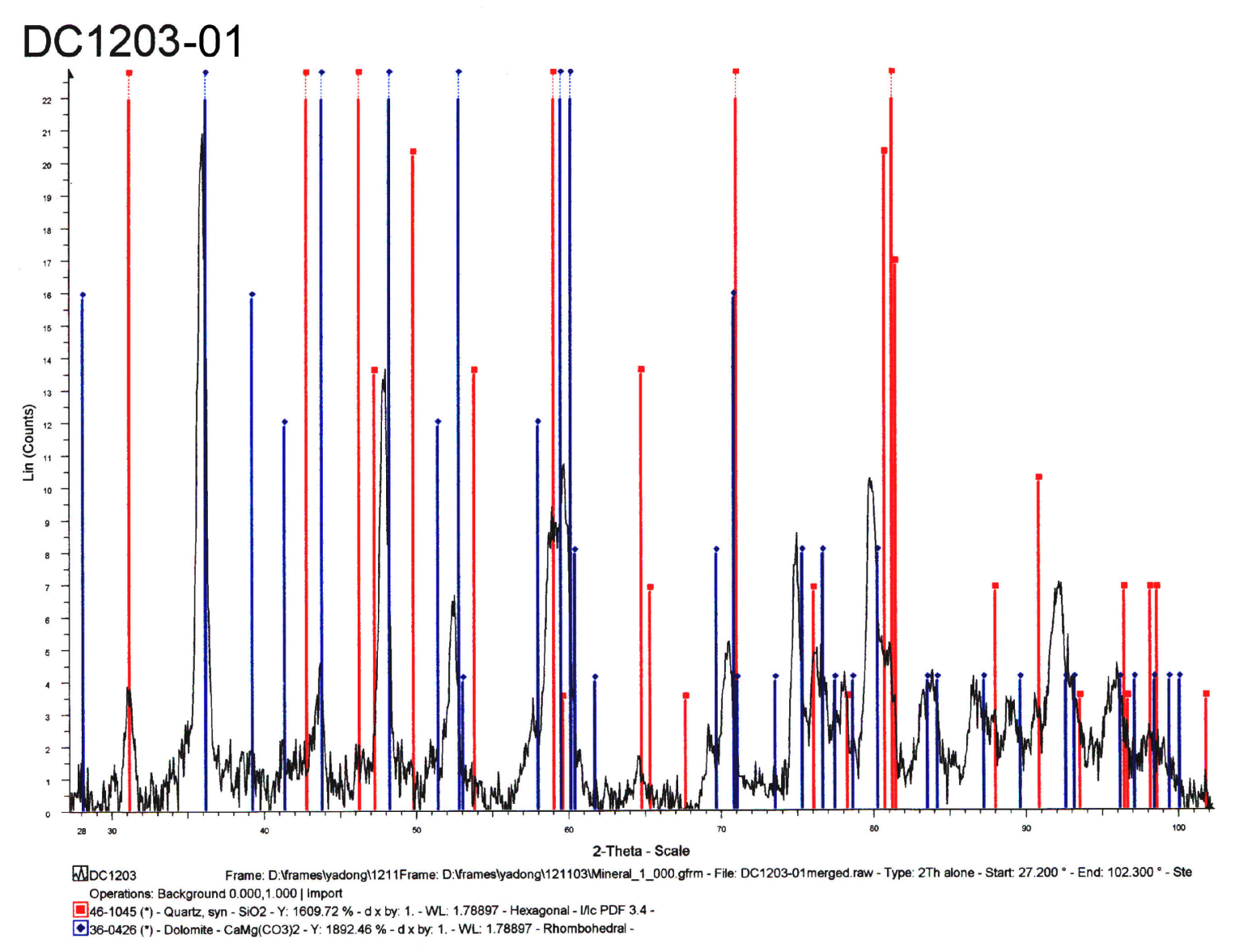




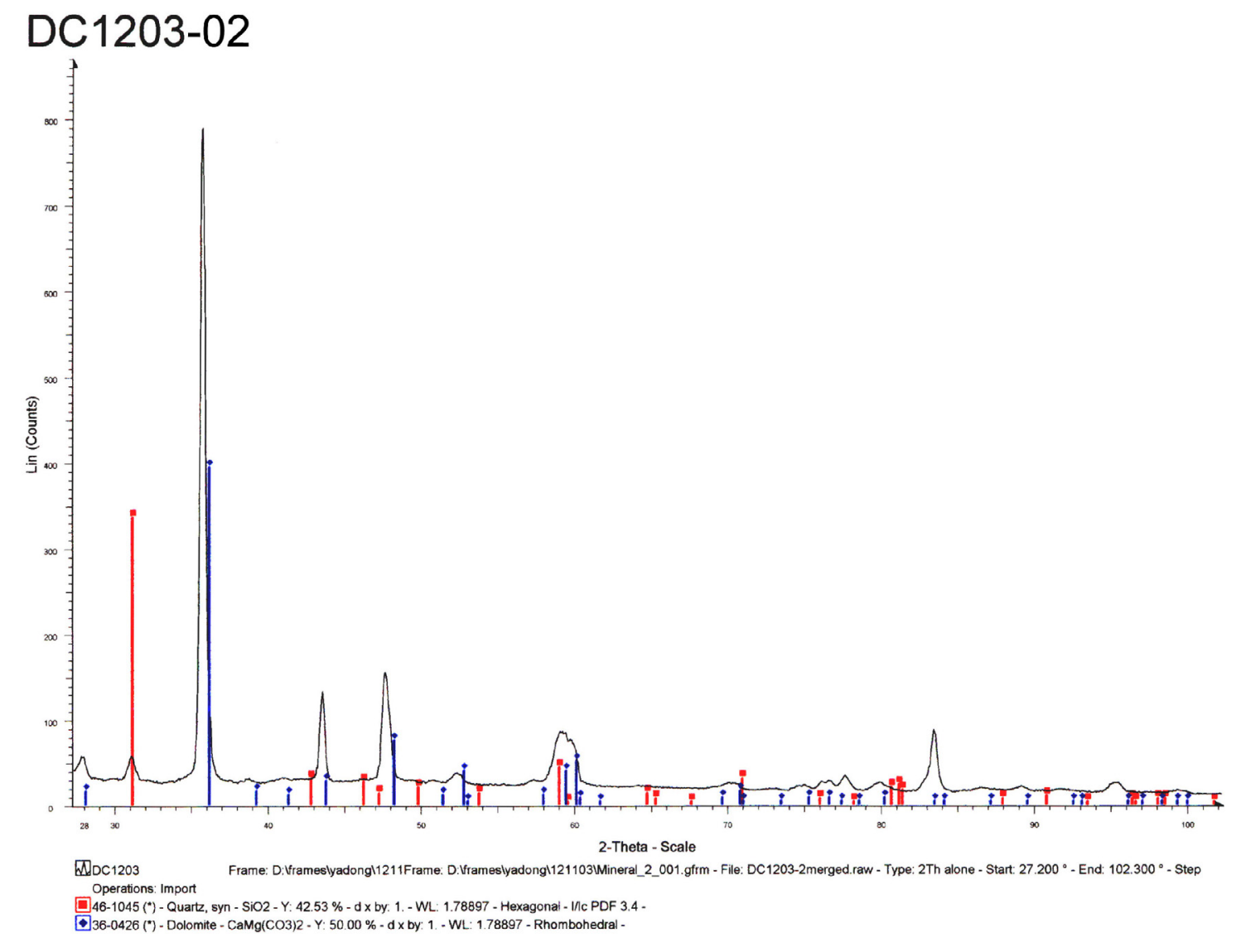




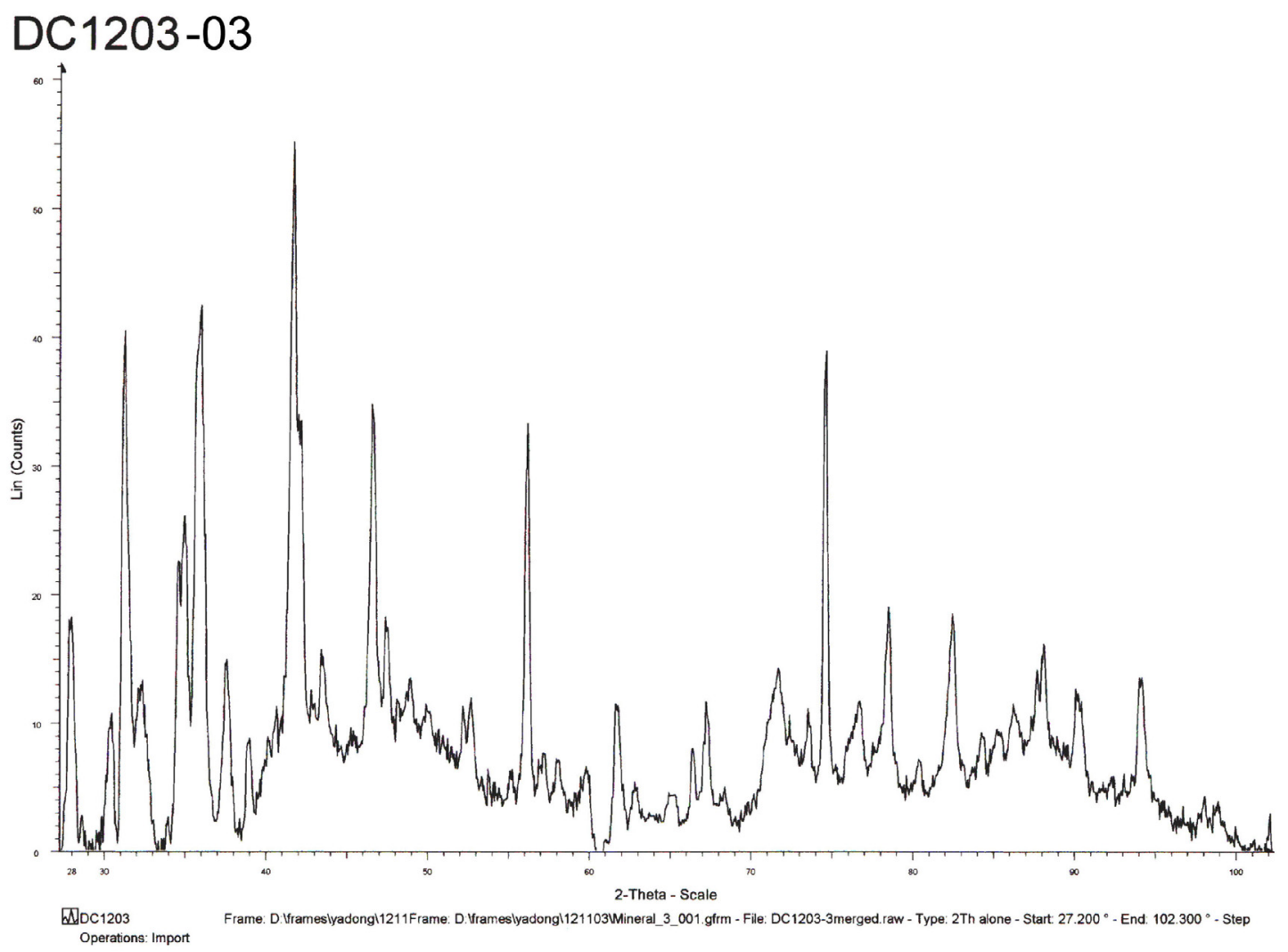




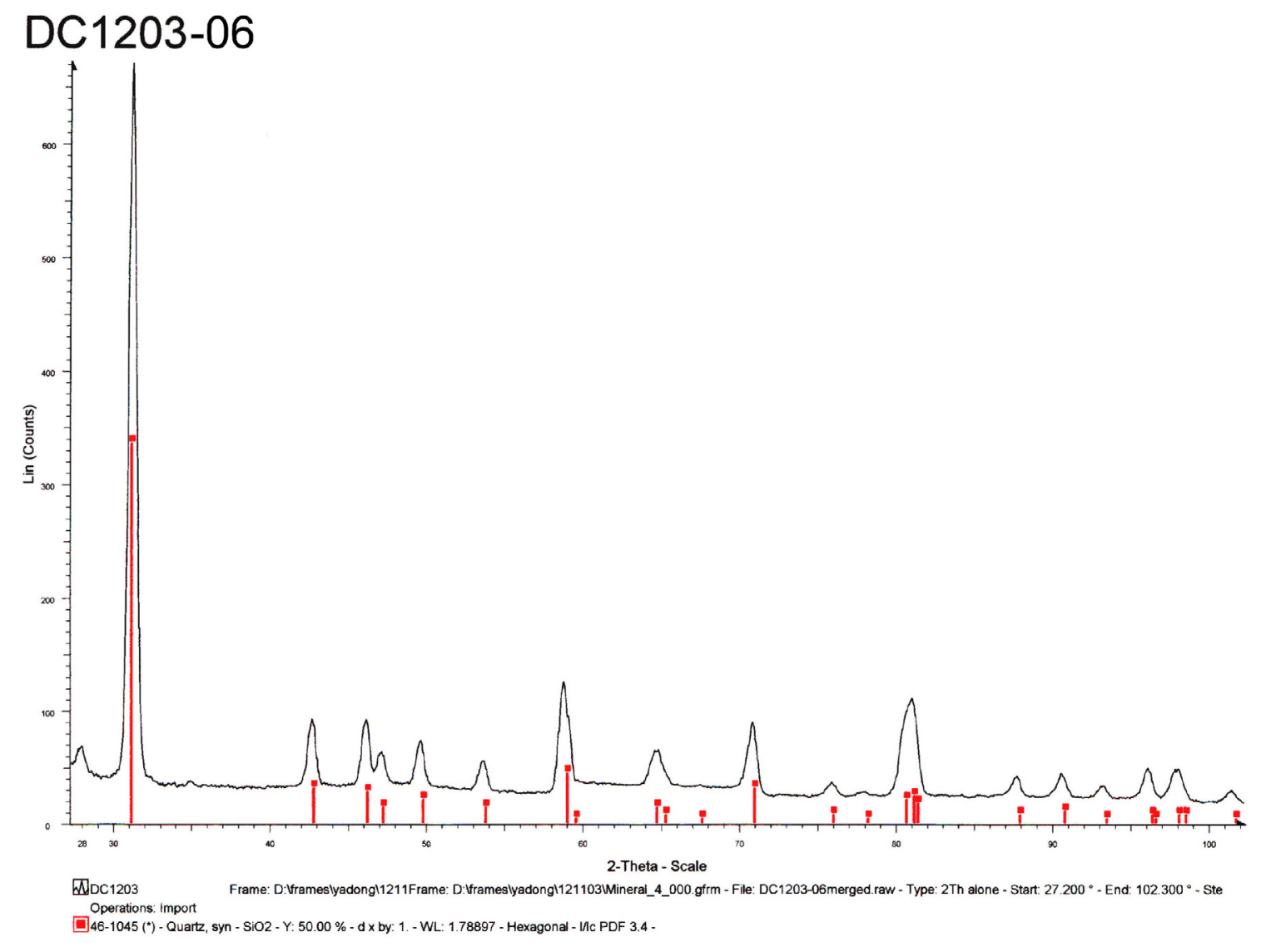




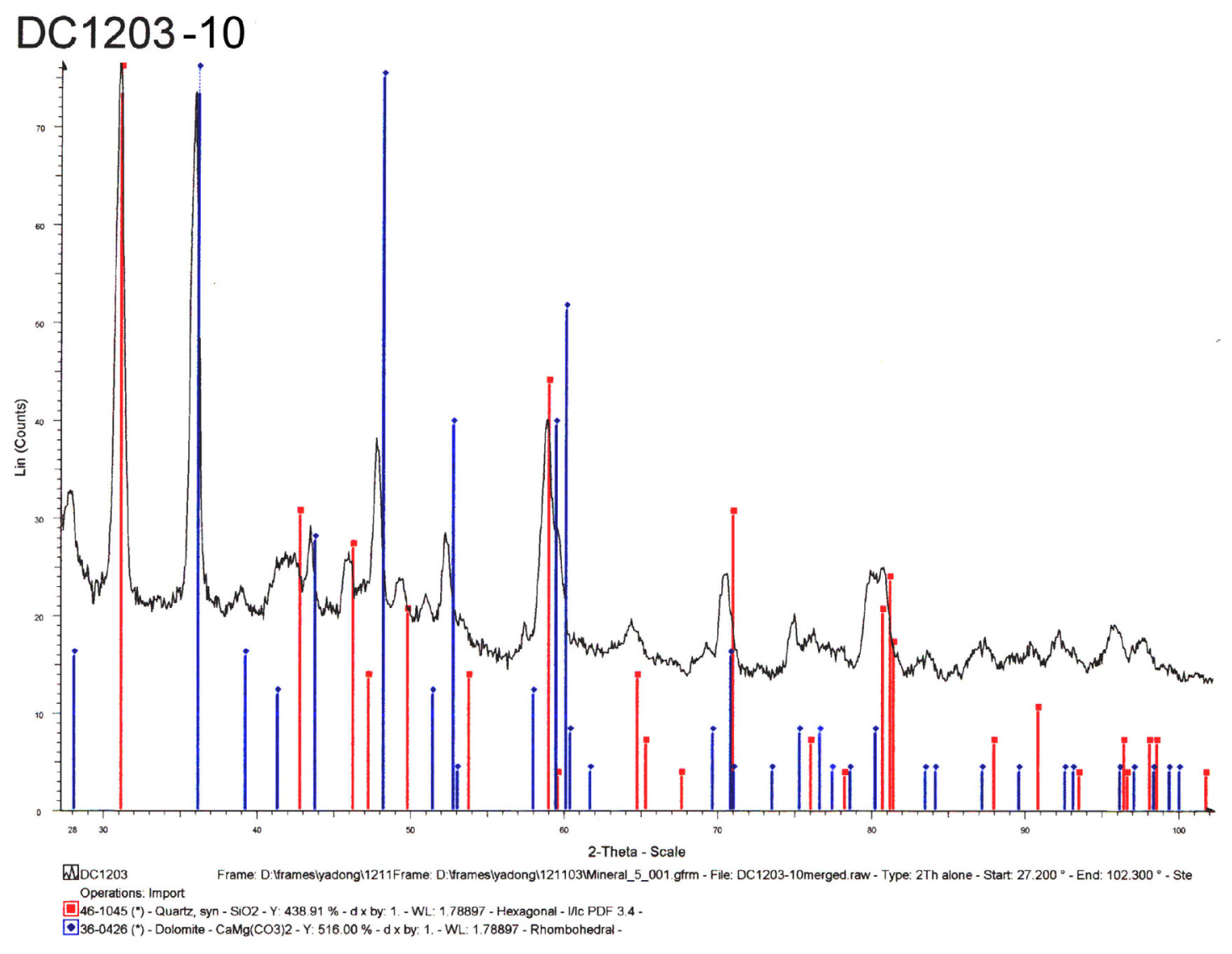




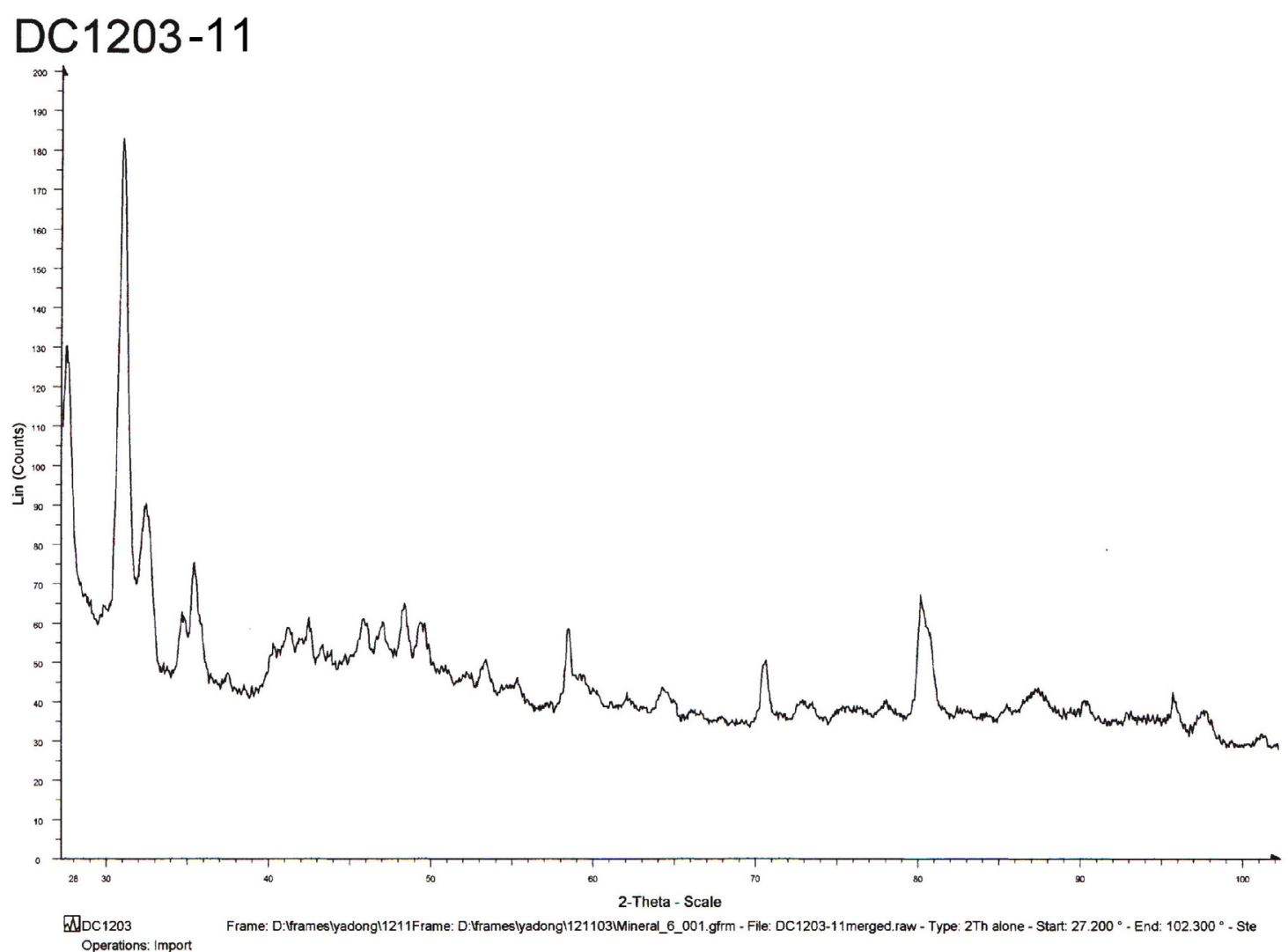

